\title{
Tax Control Framework In Tax Management Based On Tax Risk Management Control
}

\author{
Agus Tyono Amas Noer (BC202120159) \\ Arif Kurniawan (BC202120168) \\ * Graduate Student, Institut STIAMI Jakarta \\ DOI: 10.29322/IJSRP.12.01.2022.p12112 \\ http://dx.doi.org/10.29322/IJSRP.12.01.2022.p12112
}

\begin{abstract}
Tax risk management accountability will be successful if the company management creates a framework and designs control over tax risk. Tax risk will strengthen awareness within the company about the need for control over tax risk within the company.

Tests on the effectiveness of the control design consider whether the controls designed to mitigate risk have achieved the expected objectives. In addition, the accuracy or suitability of the roles and responsibilities in implementing tax risk control within the company needs to in its implementation.

Then the implementation control is carried out periodically to determine whether the performance has operated effectively in the testing period. For example, testing is carrying on the working reconciliation papers review process by taking samples of reconciliation working papers in several tax periods. The purpose of testing tax risk controls is to identify and evaluate control elements that significantly impact the company's Management of tax risk.
\end{abstract}

Keywords: tax control framework, tax compliance risk management, tcf and CRM

\section{BACKGROUND}

Compliance risk management (CRM) is a comprehensive process of taxpayer compliance risk management that includes identification, mapping, modelling, and mitigation of taxpayer compliance risks and their evaluation. In addition to the CRM system, the Directorate General of Taxes (DGT) also seeks to increase taxpayer compliance. Among other things, relaxation of input tax crediting rights for taxable entrepreneurs (PKP) and rearrangement of administrative tax sanctions and interest rewards contained in the tax cluster of the Job Creation Act or the Omnibus Law.

A systematic, measurable, and objective framework will create through a series of CRM processes. In simpler terms, CRM can define as taxpayer compliance risk management carried out systematically by the DGT.

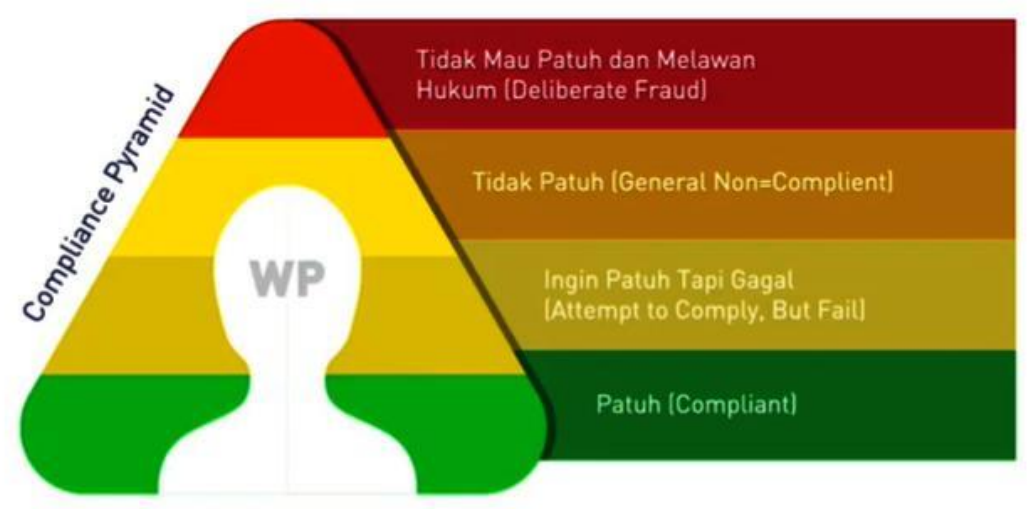

This publication is licensed under Creative Commons Attribution CC BY. 
CRM will use these risks to analyze taxpayer compliance based on a specific formula or provision. The results of this risk analysis processing into a taxpayer compliance map consisting of three compliance maps based on their function.

First, the CRM compliance map of the extensification function is a map that describes the compliance risk of taxpayers in registering to be given a Taxpayer Identification Number. This map is compiled based on the level of possible non-compliance and the level of taxpayer contribution to revenue.

Second, the CRM compliance map of the inspection and supervision function is a map that describes the taxpayer's compliance risk in reporting, paying, and reporting correctness. This map is compiled based on the level of possible non-compliance and the level of taxpayer contribution to revenue.

Third, the billing function's CRM compliance map is a map that describes the taxpayer's compliance risk in paying tax receivables. This map is prepared based on the level of the collectibility of tax receivables, the presence of the Taxpayer and the Tax Insurer, and the ability to pay.

CRM can clearly describe the compliance map from taxpayers. To determine the proper treatment for each taxpayer, understand the compliance behaviour of taxpayers, to be able to optimize resource allocation. Furthermore, CRM will continue to develop to maximize extensification, supervision, inspection, and billing functions.

The current implementation and development of CRM technology by the DGT is unfortunately not accompanied by the recent development of application tools or Taxation data management systems. CRM technology is already available or a kind of Tax Control Framework (TCF) that currently exists, such as e-Bupot, Web e-invoicing, e-commerce -SPT, etc. It is still not integrated directly in real-time on the records of taxpayer transactions that occur. If this can be provided by the DGT, of course, it will aim to assist and be used by taxpayers in mitigating and minimizing their current and future tax risks. Will come.

\section{THEORETICAL BASIS}

Tax risk management is part of the company's internal control system (Arum, 2019). The company's activities in managing tax risk include analyzing activities, providing risk ratings and priority scales, and preparing risk mitigation and control measures (Wulan, 2020). Through tax risk assessment, company management can identify and understand the company's tax risk profile.

According to the OECD Guidance Note (2009), the main objective of tax risk governance is to identify, analyze and determine the level of tax risk.

Therefore, an individual, corporate entity, or group of companies must formulate tax risk management policies and procedures through a Tax Control Framework (TAX CONTROL FRAMEWORK) (OECD, 2013).

Risk is always associated with uncertainty. This uncertainty occurs because of the lack or unavailability of information regarding what will happen. The definition of risk according to ISO 31000:2009 states that risk is the impact of uncertainty on the achievement of objectives. The effect here is the deviation from expected, which is usually positive and harmful.

According to (Ashworth), risk management identifies threats and implements measures to reduce the occurrence of these threats and minimize any damage. Risk analysis and risk control form the basis of risk management, where risk control is the application of appropriate Management to balance security, use and cost.

\section{ANALYSIS METHOD}

The author uses the experimental method, namely researching how to find a way out as a solution to implementing this taxation tax control framework. According to Sugiyono (2009:107), "Experimental research method is a research method used to find the effect of certain treatments on others under controlled conditions."

The form of experimental design used in this study is to experiment, directly aiming to prove research.

This publication is licensed under Creative Commons Attribution CC BY. 
No. Telephone/Fax : 02150501500

E-mail : klikpajak@mekari.com

Website : klikpajak.id

Services provided:

1. Distribution of SPT in the Form of Electronic Documents

2. Provision of Billing Code generation applications

3. Host-to-Host $(\mathrm{H} 2 \mathrm{H})$ e-Invoicing

4. Provision of Applications for Making and Distributing Electronic Withholding Proofs

5. Provision of Taxpayer Identification Number (NPWP) for Individual Employee Taxpayers

6. Provision of the SPT Application in the Form of Electronic Documents

Other Services

1. Tax Software

2. Accounting Software

3. HR / Payroll Software

It can see from the above description as a software company PT. Journal Consulting Indonesia has now provided a PJAP application through www.klikpajak.id where we know that initially, PT Jurnal Consulting Indonesia was a company that provided the best and most reliable financial accounting system in Indonesia under the name www.jurnal.id. This financial accounting system proved to be very useful. For Individuals who do Bookkeeping, MSMEs and even Enterprise level companies.

Jurnal.id accounting software is equipped with various features to support bookkeeping, finance, and operational processes through automation \& integration. They are making it easier for users to carry out the bookkeeping process without having to repeat from one system to another, such as the Taxation system in Indonesia, because it has been integrated and automated.

The main feature in the use of the jurnal.id financial accounting system that allows it to use which can also integrate with the PJAP system, namely klikpajak.id, is as follows:

\section{A. Financial \& business reports}

The Journal's financial report application feature will create financial reports in real-time to provide detailed and accurate company financial report software data. Comprehensive financial statements where we can view financial information, access anytime and anywhere when needed.

\section{B. Accounting}

The Journal accounting application can process bookkeeping two times faster and doesn't bother you at the end of the month. Not only expenses and income but the Journal's financial statements equipped with a Balance Sheet, Profit and Loss Report and Cash Flow. Wherefrom the output in the form of financial statements, it is possible to be an attachment to the Annual SPT from Taxpayers who use the jurnal.id system.

The components of the jurnal.id accounting process is as follows:

1. Recording of Sales, Purchases and Cost Transactions.

This publication is licensed under Creative Commons Attribution CC BY.

http://dx.doi.org/10.29322/IJSRP.12.01.2022.p12112

WWW.ijsrp.org 
ISSN 2250-3153

All Sales and Purchase transaction activities are provided concisely and can provide information on the current status of existing transactions quickly and accurately. In the Sales and Purchases module provided by jurnal.id, it is possible to calculate the tax imposition of every transaction that occurs. So that taxpayers who use it will enable them to know the nominal value of their tax obligations on their business, all PPH and VAT aspects are possible in automatically formulating every transaction between tax subjects and the Tax Object that transacts.

\section{CoA (List of Accounts)}

To track, compare or analyze bookkeeping data for small businesses, cooperatives or companies, as a standard in the accounting process, usually using a List of Accounts that has been systematically and structured in the business bookkeeping application from the Journal.

\section{General Ledger (Ledger)}

Bookkeeping reports are made easy with all transaction details recorded neatly through an automatic and thorough bookkeeping program, thereby reducing errors in storing all your important business transactions and accounts.

\section{Trial Balance}

Each transaction will be automatically attached to a trial balance report that can directly matched. The Journal also performs automatic checks and balances, ensuring the debit and credit amounts are the same.

\section{Journal Recording}

record all forms of company bookkeeping in terms of income, expenses and others through an automated application system that can make general journals easily, quickly, and in detail.

\section{Digital transaction attachment}

We don't worry about losing proof of transactions. Journal bookkeeping software features equipping with digital transaction attachment features that are easy to track via paperless files that are easy to store.

\section{Ease of automatic bookkeeping}

- Various benefits from a simple and automatic bookkeeping application will make it easier for you to compile reports from stores and cooperatives to companies accurately, efficiently, and quickly. Financial transactions arranged by category

- Ease of approving automatic match suggestions and making changes and additions to reports

- Easily create and export business summaries

C. Cash \& Bank

Input feature for all incoming and outgoing cash/bank transactions related to the Bank via Management Account Payable (Debt) \& Account Receivable (Receivable). You can also easily manage financial positions from various accounts in real-time, such as: Displaying real-time economic posts in different cash/bank accounts and tracking/recording transfers, receiving \& sending money.

The jurnal.id bank reconciliation feature has automatically equipped with direct feeds connected to Cashlink Bank Feed. You don't need to copy the account mutation manually because the mutation data will automatically record in your journal account. All you have to do is consolidate each mutation record from the bank account. In addition, it serves with a direct feeds feature that allows you to make direct matches quickly and accurately for all types of cash and bank transaction activities in your business. The transaction matching process made easy because the Journal has connected to various well-known banks in Indonesia such as BCA Corporate, BCA Personal, MANDIRI, CIMB Niaga, BNI, BNI Syariah and Bank Danamon.

This publication is licensed under Creative Commons Attribution CC BY. 


\section{Tax reporting}

Jurnal.id can do tax calculations that can do automatically. Everything becomes faster, safer and more effective. Manage and calculate taxes automatically and according to the rules in Indonesia. Starting from making tax invoices, reporting, and filing, all of these features are possible if you use jurnal.id.

Automatic sales tax calculations and reports for taxpayers review sales activity through tax reports that display a summary of tax calculations tailored to the type of transaction. The above is possible because it integrates with Klikpajak, DGT's official partner PJAP, to efficiently pay and manage taxes.

\section{E. Products \& Inventory}

Complete control over your goods' information and stock status with inventory software \& applications from the Journal. Complete with stock-taking application features as well as inventory and storage reports.

Simplify the stock management process for raw materials or products often purchased simultaneously. So that all stock is immediately updated in one click, such as Management of raw material stock to finished products, Monitoring the price of components of finished products and Composition of product bundling (manufacturing) for production.

The OECD (2016) identified six crucial points from the Tax Control Framework, as follows:

determination of the tax strategy is the first step. This strategy relates to the direction or guidance from the company's Board of Directors on risk management, risk tolerance, decision making in tax planning, and policies in tax reporting and payment.

Second, the implementation carrying comprehensively. Its means the design and operation of the TAX CONTROL FRAMEWORK must be able to cover tax risk in all company activities, both on routine and non-routine transactions, and in every stage of the business process, as well as at all levels of Management. Identify the tax consequences and treatment of each material transaction. The tax department must be involved in all stages of the transaction process, from planning to transaction implementation.

Third, there is a division of responsibilities. It relates to the division of roles and responsibilities among the Board of Directors, Senior Management, and the corporate tax department. The Board of Directors is responsible for the TAX CONTROL FRAMEWORK's design, implementation, and effectiveness. Senior Management is responsible for developing the tax strategy with the approval and supervision of the Board of Directors. Meanwhile, the tax department is responsible for implementing the plan.

Fourth, I will document the tax management process. The entire process of managing tax risk, including control elements such as approval, authorization, review, and reconciliation, must be documented. Included is the statement of the Board of Directors that the company effectively has control and monitoring of the tax management process within the company.

Fifth, there is a test on the TAX CONTROL FRAMEWORK. It relates to monitoring and improving the control framework and testing the effectiveness of the design and operation of the TAX CONTROL FRAMEWORK. Companies can involve internal or external auditors in conducting the TAX CONTROL FRAMEWORK tests. In addition, the tax authorities can perform tests on the TAX CONTROL FRAMEWORK to verify the effectiveness of the design and operation of the TAX CONTROL FRAMEWORK.

Sixth, there is a guarantee. It relates to the overall result of the previous five points, and granting a contract is possible if the last five points function effectively within the TAX CONTROL FRAMEWORK. In other words, TAX CONTROL FRAMEWORK can assure stakeholders, including tax authorities, that tax risks can control tax reports.

Under the OECD (2016) statement above, by drawing a correlation on PT's financial and tax accounting system. Journal of Consulting Indonesia, the six components to handle the company's internal control, have met the required criteria and conditions to realize a mechanism as a Tax Control Framework to fulfil its tax obligations obediently and sustainably.

This publication is licensed under Creative Commons Attribution CC BY. 


\section{CONCLUSION}

OECD (2016) states that no TAX CONTROL FRAMEWORK standard applies equally to all companies (no one size fits all) because the company's internal control system reflects certain conditions of each business activity and industry. Nevertheless, the six crucial points of TAX CONTROL FRAMEWORK above serve as a guide in designing TAX CONTROL FRAMEWORK within the company.

In designing the TAX CONTROL FRAMEWORK, the company needs to assess the current state of tax risk management. Assessment carries non four main components in managing corporate tax risk, namely, (i) risk management policies and procedures, (ii) capacity and competence of human resources in tax management within the company, (iii) tax management business processes, and (iv) data processing and information technology systems (Erle, 2008).

The assessment focuses on how the four components identify, measure risk levels, and mitigate risks through risk control and monitoring. The evaluation results of the risk management condition are then processed and dissected using gap analysis. They compare the ideal risk management conditions with the current ones.

Whatever the form of the taxpayer's implementation mechanism of the Tax Control Framework, the TAX CONTROL FRAMEWORK is continuously researched and monitored for its implementation, accompanied by training and socialization to the tax department and other relevant business units. Finally, testing and monitoring of the effectiveness of the design and operation of the TAX CONTROL FRAMEWORK's design and operation periodically.

In this case, the Directorate General of Taxes, the government needs to encourage companies such as PT. Journal of Consulting Indonesia to become the central platform and socialize taxpayers to implement the Tax Control Framework mechanism in fulfilling their tax obligations. In addition to the existence of the Tax Control Framework mechanism, it will significantly increase the compliance and extensification of taxpayers in Indonesia.

\section{REFERENCES}

OECD Book, 2016

Darmawi, Herman, 2002. Manajemen Resiko, Jakarta : Bumi Aksara

Hidayat, Nur 2013, Menerapkan Manajemen Resiko dalam mengelola Perpajakan Perusahaan, Jurnal Akuntansi Keuangan Desember 2013

https://www.pajakonline.com/optimalisasi-sistem-crm-tingkatkan-kepatuhan-wajib-pajak/

https://news.ddtc.co.id/apa-itu-crm-18714

https://news.ddtc.co.id/penilaian-dan-pengendalian-risiko-pajak-21055

https://news.ddtc.co.id/bagaimana-mengelola-risiko-pajak-21012

https://news.ddtc.co.id/hubungan-antara-transparansi-kepastian-dan-tax-control-framework-20948

https://raharja.ac.id/2020/10/29/penelitian-kualitatif/

https://accurate.id/ekonomi-keuangan/pengertian-pjap-dalam-reformasi-sistem-perpajakan/

https://mekari.com/produk/jurnal/

https://news.ddtc.co.id/tax-control-framework-dan-sistem-pengendalian-internal-perusahaan-20952

\section{AUTHORS}

First Author - Agus Tyono Amas Noer, Graduated Student, Institut STIAMI Jakarta, email: agustyono@ gmail.com Second Authors - Arif Kurniawan, Graduated Student, Institut STIAMI Jakarta, email: pelaksanakotalumpur@gmail.com Correspondence Author - Agus Tyono, Institut STIAMI Jakarta, +62-853-9991-8881

Arif Kurniawan, Institut STIAMI Jakarta, +62-821-3553-0507

This publication is licensed under Creative Commons Attribution CC BY.

http://dx.doi.org/10.29322/IJSRP.12.01.2022.p12112

WwW.ijsrp.org 